\title{
Preface
}

\section{8th Alexander von Humbolt Conference of EGU Topical Conference Series "Natural Disasters, Global Change, and the Preservation of World Heritage Sites"}

\author{
K. Tokeshi \\ Institute for Infrastructure Engineering, University of Western Sydney, Locked Bag 1797, Penrith, NSW 2751, Australia
}

Correspondence to: K. Tokeshi (k.tokeshi@uws.edu.au)

This Special Issue of Advances in Geosciences contents 18 selected papers from the 8th Alexander von Humbolt International Conference on Natural Disasters, Global Change, and the Preservation of World Heritage Sites held at Cusco (Peru) from 12 to 16 November 2012; a conference organized under the framework of Conference Series of the European Geosciences Union (EGU) in collaboration with the Universidad Nacional San Antonio Abad del Cusco - UNSAAC (Peru) as the local organizer.

The World Heritage Operational Guidelines of the United Nations Scientific, Educational, and Cultural Organization (UNESCO) states that "The cultural heritage and the natural heritage are among the priceless and irreplaceable possessions, not only of each nation, but of mankind as a whole. The loss, through deterioration or disappearance, of any of these most prized possessions constitutes an impoverishment of the heritage of all the peoples in the world. Parts of that heritage, because of their exceptional qualities, can be considered to be of outstanding universal value and as such worthy of special protection against the dangers which increasingly threaten them". However, throughout human history, natural disasters, such as earthquakes, landslides, volcanic eruptions, flooding, etc., have damaged or destroyed several historical sites around the world. Likewise, global change due to human activities is adding a new dimension to present conjuncture.

In the last decades, thanks to the technological development of instruments, software, and data acquisition systems, fields such as geo-environmental engineering, along with geophysical/geotechnical investigations, are providing better tools for disaster prevention of manmade buildings, which are of great importance also for historical sites. Thus, the aim of this international conference was to bring together geoscientists, engineers, seismologists, geologists, architects, and other specialists, to discuss natural disasters and their prevention, with particular emphasis on World Heritage sites.

From these selected papers, three were related to modelling of precipitation data. A parameter estimation problem to weight the ensemble of precipitation forecasts from different convective parameterizations in the Brazilian developments on the Regional Atmospheric Modelling System (BRAMS) is discussed by dos Santos et al. (2013). The goal was to find the best combination of the weights to reproduce the rainfall observed over South America during 2006. Another research paper related to an Artificial Neural Networks (ANNs) approach to reproduce the precipitation anomalies for the rainy seasons over the Northeast of Brazil during 1982-2009 was presented by Silva and Mendes (2013). Also, another paper related to the synoptic environment associated with a heavy rainfall event on the coastland of the Northeast of Brazil was reported by Oliveira et al. (2013).

In order to assess the risk analysis of landslides that might cause a heavy toll in human lives in Central Africa, Demarée and Van de Vyver (2013) used dataset for more than $20 \mathrm{yr}$ of operation gathered by rain gauges at three stations to establish the Intensity-Duration-Frequency (IDF) curves in the mountainous areas of Rwanda. The van Montfort technique was applied to convert data from fixed-hour intervals into data of arbitrary starting intervals. In another paper related to the assessment of landslides, Vessia et al. (2013) presented the application of the Newmark's sliding block approach to predict possible permanent displacements in landslide-prone areas in Castelfranci (Campania, Italy). 
Concerning to geophysical processes in the Earth, three research papers are presented in this special issue. Sasorova et al. (2013) discussed on the distribution of "critical latitudes" of geophysical phenomena in the rotating solid Earth, such as earthquakes, hotspots, and major and super major ore deposits. Likewise, Levin et al. (2014) analyzed what kind of fundamental physical phenomena would be responsible for the generation of the anomalous latitudinal zones of the seismic activity, the hotpots, and some other geophysical processes. Finally, using available data of volcanic eruptions published in the Smithsonian Institution Catalogue in 2006, Scalera (2013) reveals evidences on the relationship between earthquakes greater than 8.4 and associated increased rate of volcanic eruptions within the South-American WadatiBenioff zone.

In relation to the application of non-destructive techniques to characterize the ground conditions of any site, Tokeshi et al. (2013) assessed the ground compaction and general geotechnical site characterization based on the application of non-invasive Multichannel Analysis of Surface Waves (MASW) and Multichannel Simulation with One Receiver (MSOR) techniques.

Concerning to 3-D modelling techniques, two papers are presented here. Bostenaru-Dan et al. (2013) applied 3-D digital models to protected areas in the centre of Bucharest (Romania) as tool for sustainable development decisions against possible hazards in the city. Another paper related to the possibilities of creating 3-D models of historical buildings and sites in Peru was presented by Hanzalová and Pavelka (2013), describing the documentation and the visualization of two historical churches and one pre-Hispanic archaeological site in Nasca region using photogrammetric and remote sensing techniques.

The effects of global climate change are discussed in three papers. Pongrácz et al. (2013) analyzed projected changes of heat waves in Hungary for the periods 2021-2050 and 2071-2100, in comparison with the reference period 19611990. Changing temperatures were simulated using outputs of regional climate model PRECIS (a high resolution limited area model) at three different global emission scenarios (A2, A1B and B2). Another paper discussing on projected future changes from several drought indices for the period 20712100 was presented by Bartholy et al. (2013) at the same global emission scenarios used by Pongrácz et al. (2013). The third paper was presented by Ma et al. (2013), who numerically modeled river discharge using runoff data obtained from a regional climate model (4.5 km spatial resolution) as input data to five main rivers in Toyama Prefecture (Japan).

An attempt to measure ice flow velocity within glaciers using Differential SAR Interferometry (DInSAR) and Offset Tracking was carried out by Riveros et al. (2013). Based on the results from Offset Tracking processing, they obtained useful displacement maps with different fast-flowing units of the Viedma glacier (Santa Cruz, Argentina). Also, Balbarani et al. (2013) attempted to remove and to correct atmospheric artifacts from interferometric synthetic aperture radar (SAR) datasets acquired between 2010 and 2011, using Global Atmospheric Model (GAM) data.

Likewise, Schneider et al. (2014) simulated a recent event occurred close to Carhuaz city in the Cordillera Blanca of Peru in 2010. An outburst flood was triggered at the glacier Lake 513 by an ice avalanche affecting the downstream communities and Carhuaz city. The complex cascades of mass movement processes are simulated using coupling different physically-based numerical models. Finally, Amador and Alfaro (2014) estimated the effects of some of the atmospheric systems, such as easterly waves, cold fronts and tropical cyclones, on socio-economic activities and potential impacts on a World Heritage Site in Costa Rica during the period 2002-2012.

Acknowledgements. All submitted manuscripts were reviewed by at least two independent reviewers. The editor would like to thank all reviewers who contributed to improve the manuscripts submitted to this special issue. Also, the editor thanks to Copernicus Publishing staff (Editorial Support and Publication Production team) for handling all submitted manuscripts during peer-review process.

\section{References}

Amador, J. A. and Alfaro, E. J.: Weather and climate socioeconomic impacts in Central America for the management and protection of world heritage sites and the Diquis Delta culture in Costa Rica (a case study), Adv. Geosci., 35, 157-167, doi:10.5194/adgeo-35-157-2014, 2014.

Balbarani, S., Euillades, P. A., Euillades, L. D., Casu, F., and Riveros, N. C.: Atmospheric corrections in interferometric synthetic aperture radar surface deformation - a case study of the city of Mendoza, Argentina, Adv. Geosci., 35, 105-113, doi:10.5194/adgeo-35-105-2013, 2013.

Bartholy, J., Pongrácz, R., and Hollósi, B.: Analysis of projected drought hazards for Hungary, Adv. Geosci., 35, 61-66, doi:10.5194/adgeo-35-61-2013, 2013.

Bostenaru-Dan, M., Panagopoulos, T., Gociman, C. O., Armas, I., Dill, A., Chiriloae, A., and Florescu, T.: The impact of hazards on the urban tissue - 3-D representation and digital databases, Adv. Geosci., 35, 45-53, doi:10.5194/adgeo-35-45-2013, 2013.

Demarée, G. R. and Van de Vyver, H.: Construction of intensityduration-frequency (IDF) curves for precipitation with annual maxima data in Rwanda, Central Africa, Adv. Geosci., 35, 1-5, doi:10.5194/adgeo-35-1-2013, 2013.

dos Santos, A. F., Freitas, S. R., de Mattos, J. G. Z., de Campos Velho, H. F., Gan, M. A., da Luz, E. F. P., and Grell, G. A.: Using the Firefly optimization method to weight an ensemble of rainfall forecasts from the Brazilian developments on the Regional Atmospheric Modeling System (BRAMS), Adv. Geosci., 35, $123-$ 136, doi:10.5194/adgeo-35-123-2013, 2013.

Hanzalová, K. and Pavelka, K.: Documentation and virtual reconstruction of historical objects in Peru damaged by an earthquake and climatic events, Adv. Geosci., 35, 67-71, doi:10.5194/adgeo35-67-2013, 2013. 
Levin, B., Domanski, A., and Sasorova, E.: Zonal concentration of some geophysical process intensity caused by tides and variations in the Earth's rotation velocity, Adv. Geosci., 35, 137-144, doi:10.5194/adgeo-35-137-2014, 2014.

Ma, X., Kawase, H., Adachi, S., Fujita, M., Takahashi, H. G., Hara, M., Ishizaki, N., Yoshikane, T., Hatsushika, H., Wakazuki, Y., and Kimura, F.: Simulating river discharge in a snowy region of Japan using output from a regional climate model, Adv. Geosci., 35, 55-60, doi:10.5194/adgeo-35-55-2013, 2013.

Oliveira, P. T., Lima, K. C., and Santos e Silva, C. M.: Synoptic environment associated with heavy rainfall events on the coastland of Northeast Brazil, Adv. Geosci., 35, 73-78, doi:10.5194/adgeo35-73-2013, 2013.

Pongrácz, R., Bartholy, J., and Bartha, E. B.: Analysis of projected changes in the occurrence of heat waves in Hungary, Adv. Geosci., 35, 115-122, doi:10.5194/adgeo-35-115-2013, 2013.

Riveros, N., Euillades, L., Euillades, P., Moreiras, S., and Balbarani, S.: Offset tracking procedure applied to high resolution SAR data on Viedma Glacier, Patagonian Andes, Argentina, Adv. Geosci., 35, 7-13, doi:10.5194/adgeo-35-7-2013, 2013.
Sasorova, E. V., Levin, B. W., and Rodkin, M. V.: A common feature in latitudinal dependence of different geophysical processes occurring on the rotating Earth, Adv. Geosci., 35, 15-21, doi:10.5194/adgeo-35-15-2013, 2013.

Scalera, G.: The vague volcano-seismic clock of the South American Pacific margin, Adv. Geosci., 35, 89-103, doi:10.5194/adgeo-35-89-2013, 2013.

Schneider, D., Huggel, C., Cochachin, A., Guillén, S., and García, J.: Mapping hazards from glacier lake outburst floods based on modelling of process cascades at Lake 513, Carhuaz, Peru, Adv Geosci., 35, 145-155, doi:10.5194/adgeo-35-145-2014, 2014.

Silva, G. A. M. and Mendes, D.: Comparison results for the CFSv2 hindcasts and statistical downscaling over the northeast of Brazil, Adv. Geosci., 35, 79-88, doi:10.5194/adgeo-35-79-2013, 2013.

Tokeshi, K., Harutoonian, P., Leo, C. J., and Liyanapathirana, S.: Use of surface waves for geotechnical engineering applications in Western Sydney, Adv. Geosci., 35, 37-44, doi:10.5194/adgeo35-37-2013, 2013.

Vessia, G., Parise, M., and Tromba, G.: A strategy to address the task of seismic micro-zoning in landslide-prone areas, Adv Geosci., 35, 23-35, doi:10.5194/adgeo-35-23-2013, 2013. 